\title{
FAKTOR - FAKTOR YANG MEMPENGARUHI PEMBERIAN SUSU FORMULA PADA BAYI YANG DIRAWAT DI RUANG NIFAS RSUP PROF. DR. R. D. KANDOU MANADO
}

\author{
${ }^{1}$ Hery Susanto \\ ${ }^{2}$ Rocky Wilar \\ ${ }^{2}$ Hesti Lestari \\ ${ }^{1}$ Kandidat Skripsi Fakultas Kedokteran Universitas Sam Ratulangi Manado \\ ${ }^{2}$ Bagian Ilmu Kesehatan Anak Fakultas Kedokteran Universitas Sam Ratulangi Manado \\ Email: herysusan7o@yahoo.com
}

\begin{abstract}
Increased formula feeding was caused by lack of knowledge about the benefits of breastfeeding, low education, aggressive promotion of infant formula, and support from health care professionals. The are several cases where the infants given formula due to several conditions, like mother is unable to produce milk, small amount of milk production, absence of nipple appearance, post-op pain, pain during breastfeeding. The following study aims to determine what factors affecting Giving Infant Formula Milk Treated in Postpartum Room Prof. Dr. R. D. Kandou Hospital Manado. This study is a descriptive design with direct interview approach. The population in this research were all treated in the maternal postpartum Prof. Dr. R. D. Kandou Hospital Manado. Conclusion: The results obtained from 50 respondents show that $66 \%$ has a good knowledge about the benefits of breastfeeding, $66 \%$ says that health care professional support given infant formula, $100 \%$ says that their closest relatives support given breastfeeding, $34 \%$ is affected the promotion of infant formula, and $34 \%$ are women without complaints of breastfeeding hindrance factor. This study recommends that mothers / parents cooperate with health care professionals cooperation in order to increase the success rate of breastfeeding.
\end{abstract}

Keywords: infant formula, breastfeeding

\begin{abstract}
Abstrak: Meningkatnya pemberian susu formula disebabkan pengetahuan kurang mengenai manfaat ASI, pendidikan yang rendah, agresifnya promosi susu formula, dukungan petugas kesehatan. Adapun bayi yang diberikan susu formula karena beberapa kondisi ibu yang mengeluh tidak keluarnya ASI, ASI kurang, puting tidak muncul, sakit bekas operasi, nyeri saat menyusui. Penelitian ini bertujuan untuk mengetahui Faktor-Faktor Apa yang mempengaruhi Pemberian Susu Formula pada Bayi yang Dirawat di Ruang Nifas RSUP Prof Dr. R. D. Kandou Manado. Penelitian ini bersifat deskriptif dengan pendekatan wawancara langsung. Populasi dalam penelitian ini adalah seluruh ibu melahirkan dirawat di ruang nifas RSUP Prof Dr. R. D. Kandou Manado. Kesimpulan: Hasil penelitian yang diperoleh dari 50 responden diketahui bahwa 66\% pengetahuan baik mengenai manfaat ASI, 66\% petugas kesehatan mendukung pemberian susu formula, $100 \%$ orang terdekat mendukung pemberian ASI, 34\% terpengaruh promosi susu formula, 34\% kondisi ibu dengan tanpa keluhan. Penelitian ini merekomendasikan agar ibu/orang tua dengan petugas kesehatan adanya kerjasama dalam keberhasilan pemberian ASI.
\end{abstract}

Kata kunci: susu formula, ASI

Air susu ibu (ASI) merupakan makanan pertama yang paling baik bagi awal kehidupan bayi karena ASI mengandung semua zat gizi yang dibutuhkan dengan 
jumlah kandungan yang tepat dan menyediakan antibodi atau zat kekebalan untuk melawan infeksi dan juga mengandung hormon untuk memacu pertumbuhan. Sehingga demikian air susu ibu (ASI) merupakan peranan penting dalam pertumbuhan, perkembangan dan kelangsungan hidup bayi. ${ }^{1}$

Pemberian susu formula yang terlalu dini dapat meningkatkan angka kesakitan (morbiditas). Berdasarkan Survei Kesehatan Nasional (SURKESNAS) tahun 2001 angka kesakitan gangguan perinatal $34,7 \%$, infeksi saluran pernapasan akut $27,6 \%$, diare $9,4 \%$, sistem pencernaan $4,3 \%$, syaraf $3,7 \%$ dan infeksi lain $1 \%{ }^{2}$

Penelitian juga mendapatkan anakanak yang tidak mendapatkan ASI mempunyai IQ (Intellectual Quotient) lebih rendah $7-8$ poin dibandingkan dengan anak-anak yang mendapatkan ASI secara eksklusif. Karena kandungan ASI terdapat nutrien yang diperlukan untuk pertumbuhan otak bayi yang tidak ada atau sedikit sekali terdapat pada susu sapi, antara lain: Taurin, Laktosa, DHA, AA, Omega-3, dan Omega-6. ${ }^{3}$

UNICEF menyebutkan bukti ilmiah yang dipublikasikan oleh jurnal Pediatrik pada tahun 2006. Terbukti bahwa bayi yang diberi susu formula memiliki resiko meninggal pada bulan pertama. Jika dibandingkan bayi yang diberi ASI ekslusif peluang kematian 25 kali lebih tinggi pada bayi yang diberi susu formula. Bertambahnya jumlah kasus kurang gizi pada anak-anak berusia di bawah 2 tahun yang sempat melanda beberapa wilayah Indonesia dapat diminimalisasi melalui pemberian ASI secara eksklusif. Karena itu, sudah seharusnya ASI eksklusif dijadikan prioritas program di Indonesia. ${ }^{4}$

Sehingga pada tahun 2006 WHO (World Health Organization) mengeluarkan Standar Pertumbuhan Anak yang kemudian diterapkan di seluruh dunia yang manyatakan pentingnya pemberian ASI saja kepada bayi sejak lahir sampai usia 6 bulan. Sesudah itu, bayi dapat diberikan makanan pendamping ASI sambil tetap disusui hingga usianya mencapai 2 tahun. $^{5}$

Pencapaian di Indonesia masih dirasakan sangat jauh dari kenyataan bila dibandingkan dengan target yang diharapkan (80\%) bayi yang mendapatkan ASI eksklusif. Berdasarkan prevalensi ASI eksklusif dari Data Survei Demografi dan Kesehatan Indonesia (1997-2007) menunjukkan adanya penurunan dari tahun ke tahun yaitu dari 40,2\% (1997) menjadi $39,5 \%$ (2003) dan terus menurun pada tahun 2007 yaitu sebanyak 32\%, sedangkan penggunaan susu formula terjadi peningkatan tiga kalinya dari 10,8 \% menjadi $32,5 \%{ }^{6}$

Penyebab menurunnya angka pemberian ASI dan peningkatan pemberian susu formula antara lain minimnya pengetahuan para ibu tentang manfaat ASI dan cara menyusui yang benar, sedikitnya pelayanan konseling laktasi dan dukungan dari petugas kesehatan, persepsi sosial budaya yang menentang pemberian ASI, keadaan yang tidak mendukung bagi para ibu yang bekerja, serta para produsen susu melancarkan pemasaran secara agresif untuk mempengaruhi sikap ibu dalam memberikan susu formula. ${ }^{7}$

Berdasarkan fenomena kurangnya pengetahuan ibu mengenai ASI eksklusif, pekerjaan, pendidikan yang berpengaruh terhadap sikap ibu yang akan mempengaruhi perilaku ibu dalam pemberian ASI. Hal ini menyebabkan hambatan dalam pencapaian target keberhasilan pemberian ASI Eksklusif secara maksimal. Berdasarkan hal tersebut maka peneliti ingin mengetahui "FaktorFaktor Yang Mempengaruhi Pemberian Susu Formula Pada Bayi Yang Dirawat Di Ruang Nifas RSUP Prof. Dr. R. D. Kandou Manado

\section{METODE PENELITIAN}

Penelitian ini bersifat deskriptif, data yang didapatkan dengan wawancara langsung kepada responden pada bulan Oktober sampai Desember 2014. Populasi dan sampel adalah seluruh ibu melahirkan yang dirawat di ruang nifas RSUP Prof. Dr. R. D. Kandou Manado, yang memenuhi 
kriteria inklusi, yaitu memberikan susu formula saja dan susu formula dengan ASI pada bayi.

\section{HASIL PENELITIAN}

Responden dari pengisian kuesioner yang kami wawancara langsung meliputi ibu yang dirawat di ruang nifas RSUP Prof. Dr. R. D. Kandou Manado. Pemilihan sampel dilaksanakan secara acak yang diharapakan masuk dalam kategori pemberian susu formula pada bayi. Kuesioner dengan mewawancarai langsung kepada 50 responden yang memenuhi kriteria inklusi.

Berdasarkan distribusi pada Tabel 1 terdapat 33 responden (66\%) yang memiliki pengetahuan baik, sedangkan yang pengetahuan kurang terdapat 17 responden (34\%).

Pada Tabel 2 dapat dilihat 50 responden dengan persentase 100\% mendapatkan dukungan dari petugas kesehatan dalam bentuk informasi pemberian ASI.

Berdasarkan Tabel 3 terdapat 33 responden dengan persentase $66 \%$ tidak mendapatkan dukungan petugas kesehatan pada tindakan pemberian Susu Formula, sedangkan terdapat 17 responden dengan persentase $40 \%$ mendapatkan dukungan petugas kesehatan pada tindakan pemberian susu formula.

Berdasarkan Tabel 4 terdapat 50 responden dengan persentase 100\% mendapatkan dukungan orang terdekat dalam pemberian ASI.

Berdasarkan tabel 5 didapatkan 17 responden dengan persentase 34\% terpengaruh promosi susu formula, 33 responden dengan persentase $66 \%$ tidak terpengaruh susu formula.

Berdasarkan Tabel 6 dapat dilihat dari tingkat pendidikan 50 responden terdapat 3 (6\%) berpendidikan SD, 11 (22\%) berpendidikan SMP, 28 (56\%) berpendidikan SMA, dan 8 suami responden (16\%) berpendidikan sarjana.

Tabel 1. Distribusi Sampel berdasarkan Pengetahuan mengenai Manfaat ASI dan Kerugian Susu Formula

\begin{tabular}{lcccccc}
\hline Pengetahuan & \multicolumn{2}{c}{ Susu formula } & \multicolumn{2}{c}{ Susu formula + ASI } & \multicolumn{2}{c}{ TOTAL } \\
& \multicolumn{1}{l}{$\mathrm{n}$} & $\%$ & $\mathrm{n}$ & $\%$ & $\mathrm{n}$ & $\%$ \\
Baik & 16 & 64 & 17 & 68 & $\mathbf{3 3}$ & $\mathbf{6 6}$ \\
Kurang & 9 & 36 & 8 & 32 & $\mathbf{1 7}$ & $\mathbf{3 4}$ \\
TOTAL & $\mathbf{2 5}$ & $\mathbf{1 0 0}$ & $\mathbf{2 5}$ & $\mathbf{1 0 0}$ & $\mathbf{5 0}$ & $\mathbf{1 0 0}$ \\
\hline
\end{tabular}

Tabel 2. Distribusi Sampel berdasarkan Dukungan Petugas Kesehatan dalam Bentuk Informasi Pemberian ASI

\begin{tabular}{llrlrrr}
\hline $\begin{array}{l}\text { Dukungan petugas } \\
\text { kesehatan }\end{array}$ & \multicolumn{2}{l}{ Susu formula } & \multicolumn{2}{c}{ Susu formula + ASI } & \multicolumn{2}{c}{ TOTAL } \\
\hline & $\mathrm{n}$ & $\%$ & $\mathrm{n}$ & $\%$ & $\mathrm{n}$ & $\%$ \\
Mendukung & 25 & 100 & 25 & 100 & $\mathbf{5 0}$ & $\mathbf{1 0 0}$ \\
Tidak mendukung & 0 & 0 & 0 & 0 & $\mathbf{0}$ & $\mathbf{0}$ \\
TOTAL & $\mathbf{2 5}$ & $\mathbf{1 0 0}$ & $\mathbf{2 5}$ & $\mathbf{1 0 0}$ & $\mathbf{5 0}$ & $\mathbf{1 0 0}$ \\
\hline
\end{tabular}


Tabel 3. Distribusi Sampel berdasarkan Dukungan Petugas Kesehatan dalam Bentuk Tindakan Pemberian Susu Formula

\begin{tabular}{llccccc}
\hline $\begin{array}{l}\text { Dukungan petugas } \\
\text { kesehatan }\end{array}$ & \multicolumn{2}{l}{ Susu formula } & \multicolumn{2}{c}{ Susu formula + ASI } & \multicolumn{2}{c}{ TOTAL } \\
\hline & $\mathrm{n}$ & $\%$ & $\mathrm{n}$ & $\%$ & $\mathrm{n}$ & $\%$ \\
Tidak mendukung & 14 & 52 & 19 & 76 & $\mathbf{3 3}$ & $\mathbf{6 6}$ \\
Mendukung & 11 & 44 & 6 & 24 & $\mathbf{1 7}$ & $\mathbf{4 0}$ \\
TOTAL & $\mathbf{2 5}$ & $\mathbf{1 0 0}$ & $\mathbf{2 5}$ & $\mathbf{1 0 0}$ & $\mathbf{5 0}$ & $\mathbf{1 0 0}$ \\
\hline
\end{tabular}

Tabel 4. Distribusi Sampel berdasarkan Dukungan Orang Terdekat

\begin{tabular}{llrlrrr}
\hline $\begin{array}{l}\text { Dukungan orang } \\
\text { terdekat }\end{array}$ & \multicolumn{2}{c}{ Susu formula } & \multicolumn{2}{c}{ Susu formula + ASI } & \multicolumn{2}{c}{ TOTAL } \\
\hline & $\mathrm{n}$ & $\%$ & $\mathrm{n}$ & $\%$ & $\mathrm{n}$ & $\%$ \\
Mendukung & 25 & 100 & 25 & 100 & $\mathbf{5 0}$ & $\mathbf{1 0 0}$ \\
Tidak mendukung & 0 & 0 & 0 & 0 & $\mathbf{0}$ & $\mathbf{0}$ \\
TOTAL & $\mathbf{2 5}$ & $\mathbf{1 0 0}$ & $\mathbf{2 5}$ & $\mathbf{1 0 0}$ & $\mathbf{5 0}$ & $\mathbf{1 0 0}$ \\
\hline
\end{tabular}

Tabel 5. Distribusi Sampel berdasarkan Promosi Susu Formula

\begin{tabular}{lcccccc}
\hline $\begin{array}{l}\text { Promosi susu } \\
\text { formula }\end{array}$ & \multicolumn{2}{c}{ Susu formula } & \multicolumn{2}{c}{ Susu formula + ASI } & \multicolumn{2}{c}{ TOTAL } \\
\hline & $\mathrm{n}$ & $\%$ & $\mathrm{n}$ & $\%$ & $\mathrm{n}$ & $\%$ \\
Terpengaruh & 9 & 36 & 8 & 32 & $\mathbf{1 7}$ & $\mathbf{3 4}$ \\
Tidak terpengaruh & 16 & 64 & 17 & 68 & $\mathbf{3 3}$ & $\mathbf{6 6}$ \\
TOTAL & $\mathbf{2 5}$ & $\mathbf{1 0 0}$ & $\mathbf{2 5}$ & $\mathbf{1 0 0}$ & $\mathbf{5 0}$ & $\mathbf{1 0 0}$ \\
\hline
\end{tabular}

Tabel 6. Distribusi Sampel berdasarkan Tingkat Pendidikan

\begin{tabular}{llrrrrr}
\hline $\begin{array}{l}\text { Tingkat } \\
\text { pendidikan }\end{array}$ & \multicolumn{2}{c}{ Susu formula } & \multicolumn{2}{c}{ Susu formula + ASI } & \multicolumn{2}{c}{ TOTAL } \\
\hline \multirow{2}{*}{ SD } & $\mathrm{n}$ & $\%$ & $\mathrm{n}$ & $\%$ & $\mathrm{n}$ & $\%$ \\
SMP & 2 & 8 & 1 & 4 & $\mathbf{3}$ & $\mathbf{6}$ \\
SMA & 7 & 28 & 4 & 16 & $\mathbf{1 1}$ & $\mathbf{2 2}$ \\
Sarjana & 11 & 44 & 17 & 68 & $\mathbf{2 8}$ & $\mathbf{5 6}$ \\
TOTAL & 5 & 20 & 3 & 12 & $\mathbf{8}$ & $\mathbf{1 6}$ \\
\hline
\end{tabular}


Berdasarkan Tabel 4.7 pekerjaan suami responden dari 50 suami responden terdapat $56 \%$ pegawai swasta, $4 \%$ pegawai negeri sipil, $10 \%$ wiraswasta, $4 \%$ polri, $10 \%$ buruh, $6 \%$ nelayan, $6 \%$ petani, $2 \%$ pengangguran, $2 \%$ mahasiswa.

Berdasarkan Tabel 4.8 dapat dilihat bahwa pekerjaan responden dari 50 responden terdapat 36 responden (72\%) ibu rumah tangga, 7 responden (14\%) pegawai swasta, 1 responden (2\%) pegawai negeri sipil, 3 responden (6\%) wiraswasta, 2 responden (4\%) perawat, 1 responden (2\%) mahasiswa.

Berdasarkan Tabel 4.9 dapat dilihat bahwa kondisi ibu dari 50 responden terdapat 13 responden (26\%) ASI tidak keluar, 15 responden (30\%) ASI kurang, 1 responden (2\%) puting tidak muncul, 3 responden $(6 \%)$ sakit bekas operasi, 1 responden (2\%) nyeri saat menyusui, 17 responden (34\%) normal.

Tabel 7. Distribusi Sampel berdasarkan Pekerjaan Suami

\begin{tabular}{llrrrrr}
\hline Pekerjaan & \multicolumn{2}{r}{ Susu formula } & \multicolumn{2}{c}{ Susu formula + ASI } & \multicolumn{2}{c}{ TOTAL } \\
& $\mathrm{n}$ & $\%$ & $\mathrm{n}$ & $\%$ & $\mathrm{n}$ & $\%$ \\
$\begin{array}{l}\text { Pegawai } \\
\text { Swasta }\end{array}$ & 9 & 36 & 19 & 76 & $\mathbf{2 8}$ & $\mathbf{5 6}$ \\
$\begin{array}{l}\text { Pegawai } \\
\text { Negeri sipil }\end{array}$ & 2 & 8 & 0 & 0 & $\mathbf{2}$ & $\mathbf{4}$ \\
Wiraswasta & 3 & 12 & 2 & 8 & $\mathbf{5}$ & $\mathbf{1 0}$ \\
Polri & 2 & 8 & 0 & 0 & $\mathbf{2}$ & $\mathbf{4}$ \\
Buruh & 4 & 16 & 1 & 4 & $\mathbf{5}$ & $\mathbf{1 0}$ \\
Nelayan & 3 & 12 & 0 & 0 & $\mathbf{3}$ & $\mathbf{6}$ \\
Petani & 1 & 4 & 2 & 8 & $\mathbf{3}$ & $\mathbf{6}$ \\
Pengangguran & 0 & 0 & 1 & 4 & $\mathbf{1}$ & $\mathbf{2}$ \\
Mahasiswa & 1 & 4 & 0 & 0 & $\mathbf{1}$ & $\mathbf{2}$ \\
TOTAL & $\mathbf{2 5}$ & $\mathbf{1 0 0}$ & $\mathbf{2 5}$ & $\mathbf{1 0 0}$ & $\mathbf{5 0}$ & $\mathbf{1 0 0}$ \\
\hline
\end{tabular}

Tabel 8. Distibusi Sampel berdasarkan Pekerjaan Istri

\begin{tabular}{llccccc}
\hline Pekerjaan & \multicolumn{2}{l}{ Susu formula } & \multicolumn{2}{c}{ Susu Fformula + ASI } & \multicolumn{2}{c}{ TOTAL } \\
& \multicolumn{1}{l}{$\mathrm{n}$} & $\%$ & $\mathrm{n}$ & $\%$ & $\mathrm{n}$ & $\%$ \\
IRT & 17 & 68 & 19 & 76 & $\mathbf{3 6}$ & $\mathbf{7 2}$ \\
Pegawai & 3 & 12 & 4 & 16 & $\mathbf{7}$ & $\mathbf{1 4}$ \\
$\begin{array}{l}\text { Swasta } \\
\text { Pegawai }\end{array}$ & 1 & 4 & 0 & 0 & $\mathbf{1}$ & $\mathbf{2}$ \\
Negeri sipil & 2 & 8 & 1 & 4 & $\mathbf{3}$ & $\mathbf{6}$ \\
Wiraswasta & 1 & 4 & 1 & 4 & $\mathbf{2}$ & $\mathbf{4}$ \\
Perawat & 1 & 4 & 0 & 0 & $\mathbf{1}$ & $\mathbf{2}$ \\
Mahasiswa & $\mathbf{2 5}$ & $\mathbf{1 0 0}$ & $\mathbf{2 5}$ & $\mathbf{1 0 0}$ & $\mathbf{5 0}$ & $\mathbf{1 0 0}$ \\
TOTAL & & & & & & \\
\hline
\end{tabular}


Tabel 9. Distibusi Sampel berdasarkan Kondisi Ibu

\begin{tabular}{llccccc}
\hline Kondisi ibu & \multicolumn{2}{l}{ Susu formula } & \multicolumn{2}{c}{ Susu formula + ASI } & \multicolumn{2}{c}{ TOTAL } \\
\hline & $\mathrm{n}$ & $\%$ & $\mathrm{n}$ & $\%$ & $\mathrm{n}$ & $\%$ \\
$\begin{array}{l}\text { ASI tidak } \\
\text { keluar }\end{array}$ & 11 & 44 & 2 & 8 & $\mathbf{1 3}$ & $\mathbf{2 6}$ \\
$\begin{array}{l}\text { ASI kurang } \\
\text { Puting tidak }\end{array}$ & 0 & 0 & 15 & 60 & $\mathbf{1 5}$ & $\mathbf{3 0}$ \\
$\begin{array}{l}\text { Muncul } \\
\text { Sakit bekas }\end{array}$ & 2 & 4 & 0 & 0 & $\mathbf{1}$ & $\mathbf{2}$ \\
$\begin{array}{l}\text { operasi } \\
\text { Nyeri saat } \\
\text { menyusui }\end{array}$ & 0 & 8 & 1 & 4 & $\mathbf{3}$ & $\mathbf{6}$ \\
$\begin{array}{l}\text { Tanpa } \\
\text { keluhan }\end{array}$ & 11 & 44 & 6 & 24 & $\mathbf{1 7}$ & $\mathbf{3 4}$ \\
TOTAL & $\mathbf{2 5}$ & $\mathbf{1 0 0}$ & $\mathbf{2 5}$ & $\mathbf{1 0 0}$ & $\mathbf{5 0}$ & $\mathbf{1 0 0}$ \\
\hline
\end{tabular}

\section{BAHASAN}

Berdasarkan Tabel 1 hasil penelitian menunjukkan responden dengan pengetahuan baik mengenai manfaat ASI dan kerugian susu formula terdapat 33 responden (66\%) yang lebih besar dibanding pengetahuan kurang yang terdapat 17 responden (34\%) dalam memberikan susu formula, meskipun pengetahuan merupakan hal yang sangat penting dalam membentuk tindakan seseorang dalam peningkatan pemberian $\mathrm{ASI}^{18}$ namun pada responden dengan pengetahuan baik pemberian susu formula tetap dilakukan.

Berdasarkan pada Tabel 2 semua responden sebanyak 50 responden dengan persentase $100 \%$ yang memberikan susu formula mengaku mendapatkan dukungan petugas kesehatan dalam bentuk informasi pemberian ASI. Edukasi mengenai pemberian ASI sangat penting dilakukan dari petugas kesehatan yang dapat mempengaruhi keputusan yang dibuat ibu. ${ }^{20}$ Pada hasil penelitian, pemberian susu formula tetap diberikan meskipun mendapatkan dukungan petugas kesehatan dalam bentuk informasi

Pada Tabel 3 dapat dilihat bahwa terdapat 33 responden (66\%) dari 50 responden tidak mendapat dukungan dari petugas kesehatan dalam tindakan pemberian Susu Formula yang memberikan susu formula. Pada hasil penelitian masih terdapat 17 responden (40\%) yang mendapatkan dukungan petugas kesehatan dalam tindakan pemberian Susu Formula, padahal peran petugas kesehatan sangat penting dalam pemilihan menyusui secara dini. $^{20}$

Hasil penelitian pada Tabel 4 didapatkan dari semua responden sebanyak 50 responden (100\%) yang memberikan susu formula mendapatkan dukungan orang terdekat dalam bentuk informasi pemberian susu formula terutama dukungan dari keluarga keluarga yang memberikan susu formula. Keputusan memberikan ASI sering dipengaruhi oleh keluarga terutama, teman, dan lingkungan sosial ibu daripada pengetahuan ibu. ${ }^{21}$

Berdasarkan hasil penelitian pada Tabel 5 menunjukkan 17 responden dengan persentase $34 \%$ memberikan susu formula yang terpengaruh pada promosi susu formula, sedangkan 33 responden dengan persentase $66 \%$ tidak terpengaruh memberikan susu formula. Didapatkan hasil dalam memberikan susu formula lebih besar pada responen yang tidak terpengaruh 
dengan promosi susu formula.

Hasil penelitian pemberian susu formula berdasarkan tingkat pendidikan pada Tabel 6 didapatkan berpendidikan SD 3 responden (6\%), SMP 11 responden (22\%), SMA 28 responden (56\%), sarjana 8 responden (16\%). Seseorang berpendidikan tinggi dan berpengetahuan luas akan lebih bisa menerima alasan untuk memberikan ASI karena pola pikirnya yang lebih realistis dibandingkan yang tingkat pendidikan rendah. ${ }^{16}$ Dari hasil penelitian responden yang berpendidikan tinggi memberikan susu formula begitu juga halnya pada responden berpendidikan rendah.

Pada Tabel 7 distribusi sampel berdasarkan pekerjaan suami menunjukkan pekerjaan 50 suami responden yang memberikan susu formula berasal dari berbagai status pekerjaan, yaitu $56 \%$ pegawai swasta, $4 \%$ pegawai negeri sipil, $10 \%$ wiraswasta, $4 \%$ polri, $10 \%$ buruh, $6 \%$ nelayan, $6 \%$ petani, $2 \%$ pengangguran, $2 \%$ mahasiswa. Berdasarkan distribusi pekerjaan responden dalam pemberian susu formula dapat dilihat pada Tabel 8 menunjukkan pekerjaan responden dari 50 responden terdapat 36 responden (72\%) ibu rumah tangga, 7 responden (14\%) pegawai swasta, 1 responden (2\%) pegawai negeri sipil, 3 responden $(6 \%)$ wiraswasta, 2 responden (4\%) perawat, 1 responden (2\%) mahasiswa. Status pekerjaan responden berasal dari berbagai status pekerjaan namun bekerja bukan alasan untuk menghentikan pemberian ASI dengan pengetahuan yang benar tentang menyusui, adanya perlengkapan memerah ASI, dan dukungan lingkungan kerja, seorang ibu yang bekerja dapat tetap memberikan ASI kepada bayinya. ${ }^{18}$

Dari hasil penelitian berdasarkan pemberian susu formula ditinjau dari kondisi ibu pada Tabel 9 menunjukkan 13 responden (26\%) ASI tidak keluar, 15 responden (30\%) ASI kurang, 1 responden (2\%) puting tidak keluar, 3 responden (6\%) sakit bekas operasi, 1 responden (2\%) nyeri saat menyusui, 17 responden (34\%) dalam keadaan normal. Didapatkan 17 responden dalam normal memberikan susu formula dan 33 responden dalam masalah kesahatan yang diderita ibu yang menyebakan hambatan pemberian ASI. ${ }^{2 \mathrm{~B}}$

\section{SIMPULAN}

Dari hasil penelitian menunjukkan bahwa banyak faktor yang dapat mempengaruhi ibu memberikan susu formula pada bayi. Faktor kondisi ibu dan dukungan petugas kesehatan sangat mempengaruhi keputusan ibu memberikan susu formula pada bayi, meskipun ibu memiliki pengetahuan baik, tingkat pendidikan tinggi, dukungan orang terdekat dan tidak terpengaruh dengan promosi susu formula.

\section{SARAN}

Perlunya kerjasama antara peranan ibu/orangtua dengan petugas kesahatan dalam keberhasilan pemberian ASI.

Perlunya komunikasi, informasi, motivasi, edukasi pada ibu/orangtua dan petugas kesehatan mengenai pentingnya pemberian ASI.

\section{DAFTAR PUSTAKA}

1. Manson JE, Bassuk SS. The menopausal transition and postmenopausal hormone therapy. In: Jameson JL, Fauci AS, Kasper DL, Braunwald E, Hauser SL, Longo DL, et al., editors. Harrison's Endocrinology (Second Edition). New York: The McGraw-Hills Companies, 2010; p. 207-15.

2. Lewis S. Makanan Pertamaku. Jakarta: Erlangga; 2004. p. 10.

3. Amiruddin R. Promosi Susu Formula Menghambat Pemberian ASI Eksklusif. 2006.http://ridwanamiruddin.wordpress .com/2007/04/26/susu-formulamenghambat-pemberian-asi-ekslusif/, diakses tanggal 14 September 2014.

4. Nurheti Y. Keajaiban ASI-Makanan Terbaik untuk Kesehatan, Kecerdasan, dan Kelincahan Si Kecil. Yogyakarta: C.V Andi; 2010. p. 5-8.

5. Pemyataan UNICEF: ASI Eksklusif Tekan Angka Kematian Bayi Indonesia. Gatra.com, http://menyusui.net/pernyataan-unicef-asieksklusif-tekan-angka-kematian-bayi- 
indonesia.html , diaksestanggal 18 September 2014.

6. WHO. Planning Guide for national implementation of the Global Strategy for Infant and Young Child Feeding, 2007

http://whqlibdoc.who.int/publications/2 007/9789241595193_eng.pdf, diakses tanggal 18 September 2014.

7. Nuryati S. Susu Formula dan Angka Kematian Bayi. 2007. http: unisosdem.org/kliping_detail.php?aid= 9674\&cold=34, diakses tanggal 8 April 2011.

8. Tasya A. Indonesia dan ASI. 2008. http://aimi-asi.org/, diakses pada tanggal 28 September 2014.

9. Muslihatun WN. Asuhan Neonatus Bayidan Balita. Yogyakarta: Fitramaya; 2010.

10. Kj. Pengganti Air Susu Ibu. 2007. http://www/balitaanda.com/balita_Peng ganti_Air_Susu_Ibu.htm. Di-akses tanggal 30 September 2014.

11. Triana H. Faktor-Faktor Yang Berhubungan Dengan Pemberian Susu Formula Pada Bayi Usia 0-6 Bulan Di Kelurahan Helvetia Timur, Tesis, FKM USU. Jakarta: 2012.

12. Febry A, Zulfito M. Buku Pintar Menu Bayi. Jakarta: Wahyu Media; 2007. h. 7.

13. Indiarti MT. ASI, Susu Formula dan Makanan Bayi. UGM. Yogyakarta: 2008.

14. Siregar A. Faktor-Faktor yang
Mempengaruhi Pemberian ASI Oleh Ibu Melahirkan. 2004. http: //library.sus.ac.id/download/fkm/fkmarifin-pdf , (diakses pada tanggal 28 September 2014).

15. Nursalam. Ilmu Kesehatan Anak. Jakarta: Salemba Medika; 2005.

16. Susilowati. Pengukuran Status Gizi dengan Antropometri Gizi. 2008.

17. Soekanto Soerjono. Sosiologi Suatu Pengantar. Jakarta: PT Rajagraindo Persada; 2002.

18. Notoadmodjo. Pendidikan dan Perilaku Kesehatan. Jakarta: Rineka Cipta; 2003.

19. Roesli Utami. Mengenal ASI Eksklusif. Jakarta: Trubus Agriwidya; 2005.

20. Purwanti. Konsep Penerapan ASI Eksklusif. Jakarta: Buku Kedokteran. EGC; 2004.

21. Piwoz E.G., Ferguson Y.O., Bentley M.E, Corneli A.L. Moses A., \&Nkhoma J. Differences between International Recommendations on Breastfeeding and HIV and Health Workers' Attitudes and Counseling Practices in Lilongwe, Malawi. International Breastfeeding Journal. 2006; 1-8.

22. Olds S B, London ML, Ladewig $P$ W, Davidson MR. Maternal Newborn Nursing and Women's health Care, NJ: Prentice Hall. 2004.

23. Widodo, PT. Faktor-Faktor Yang Mempengaruhi Pemberian ASI saja di Indonesia [Tesis]. Depok: 2007. 